\title{
ECOLOGICAL RISK AND ECONOMIC LOSS ESTIMATION OF HEAVY METALS POLLUTION IN THE BEIJIANG RIVER
}

\author{
OCENA RYZYKA EKOLOGICZNEGO I STRAT EKONOMICZNYCH \\ WYNIKAJĄCYCH Z ZANIECZYSZCZENIA METALAMI CIĘŻKIMI \\ RZEKI BEIJIANG
}

\begin{abstract}
The distribution and extent of heavy metal accumulation in the fluvial sediment of the Beijiang River are described. The potential toxicity of this pollution was quantified using a consensus based sediment quality guidelines (SQGs) method and the Hakanson potential ecological risk index. The concentrations of $\mathrm{Hg}, \mathrm{As}, \mathrm{Cu}$, $\mathrm{Zn}, \mathrm{Pb}, \mathrm{Ni}$ and $\mathrm{Cr}$ were high enough to damage the sediment biota on a frequent basis. The potential ecological risk was much higher in the downstream, urbanized reaches of the river than in the upstream reaches which are still rural, but all sections of the river posed at least a moderate level of ecological risk. Estimates of the economic loss associated with these pollutions were appreciable, and were mainly due to $\mathrm{Hg}$ and $\mathrm{Cu}$. The Beijiang River basin is heavily polluted, posing environmental risks for the downstream reaches of the Pearl River, and economic loss to the whole watershed.
\end{abstract}

Keywords: ecological risk assessment, economic loss estimation, heavy metals, sediment, ecosystem service, Beijiang River

\section{Introduction}

The pollution of aquatic ecosystems by heavy metals, driven by increasing urbanization and industrialization, is a growing global problem [1]. The accumulation of heavy metals in fluvial sediments has a major impact on riverine biota [2] and the health of local human populations [3], particularly as these pollutants are so readily released into the water in response to changes in environment [4]. River sediments act as a sink for various pollutants, and in so doing provide a record of anthropogenic emissions. An accurate assessment of

\footnotetext{
${ }^{1}$ Guanghua School of Management Peking University, Beijing, 100871, China

2 Jiangxi Provincial Center for Environment Monitoring, Nanchang 330077, China

${ }^{3}$ School of Environmental Science and Engineering, Anhui Normal University, Wuhu 241003, China

${ }^{4}$ College of Resources and Environment, Huazhong Agricultural University, Wuhan, 430070, China, phone +8615871384900

${ }^{5}$ Wuhan Polytechnic University, Wuhan, 430070, China

*Corresponding author: Songmw165@hotmail.com
} 
water quality, alongside the environmental risk associated with the heavy metal contamination of the sediment, are prerequisites for proposing strategies aimed at environmental management and economic development, and the estimation of potential economic losses is a key consideration for any such strategy [5]. The assessment of the ecological risk of heavy metal pollution in sediments is currently based on various sediment quality standards [6-8], among which sediment quality guidelines (SQGs) have proven to be particularly suitable [9]. However, as yet, little attention has been paid to either the ecological risk or the extent of economic losses at the level of a whole watershed.

The Beijiang River, a tributary of the Pearl River in southern China, provides a source of drinking water for over a million people, but its water quality is being continuously degraded by the discharge of industrial and domestic waste water [10]. Here, we have applied a consensus-based SQG method and the Hakanson potential ecological risk index [11] to assess the extent of the ecological damage and the economic loss [12] caused by heavy metal pollution in the Beijiang River basin.

\section{Materials and methods}

\section{Study area and sampling sites}

The $468 \mathrm{~km}$ long Beijiang River flows to the north of Guangzhou City and joins the Pearl River at Foshan City. Its $38,832 \mathrm{~km}^{2}$ watershed receives an annual volume of $4.82 \times 1010 \mathrm{~m}^{3}$ runoff water [13].

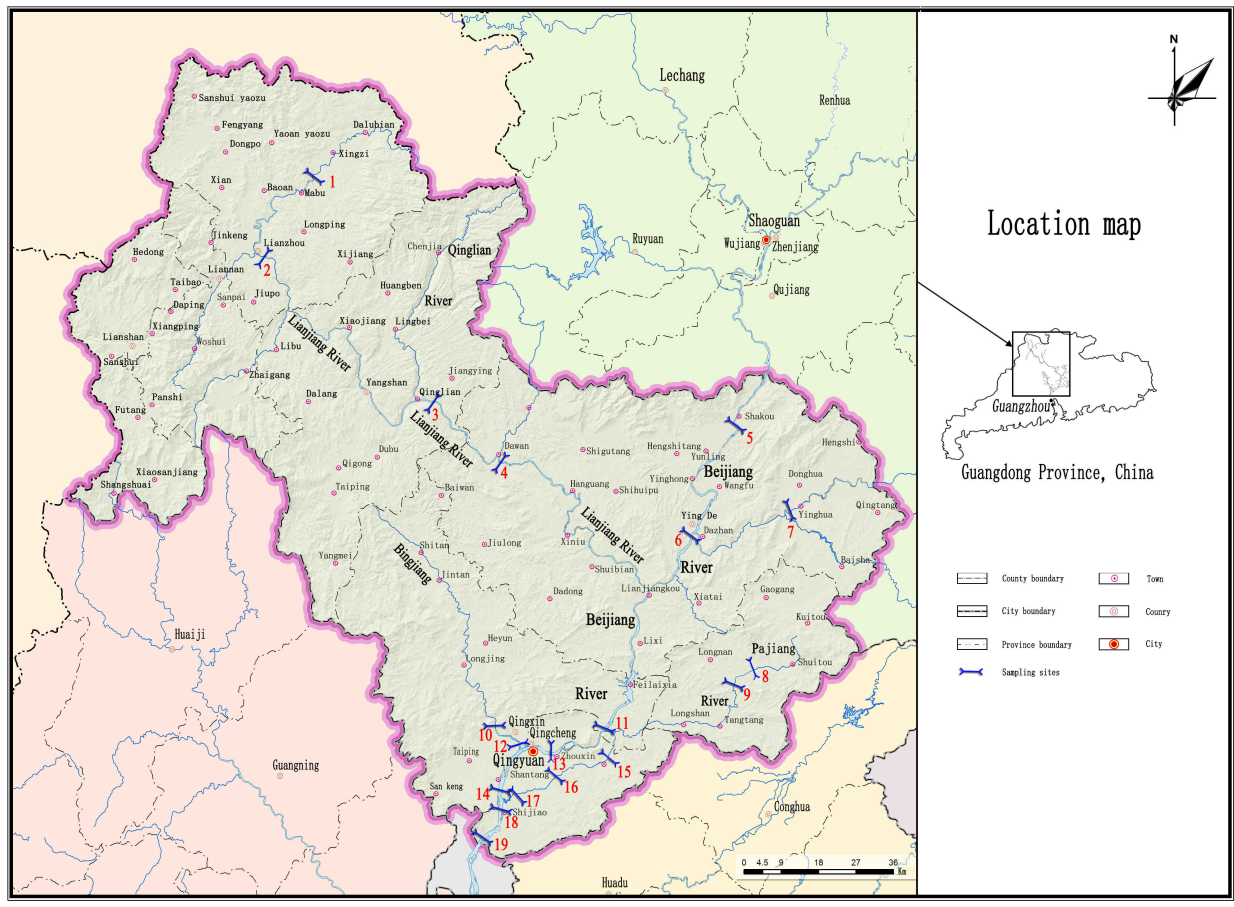

Fig. 1. Map of study area and sampling stations 
More than $80 \%$ of the total flow takes place between April and September, with the maximum to minimum discharge ratio varying from three to six fold [14]. The development of mining and industry, accompanied by rapid urbanization, has given rise to a growing water pollution problem in the river basin [10]. The study involved the monitoring of 19 sites, the locations of which are given in Figure 1. Sites \#1-\#10 are located in the upstream reaches of the river, and are surrounded by agricultural land, involving the cultivation of rice and vegetables. The area is composed mostly of Cretaceous chalk. Sites \#11-\#19 are located within the urbanized part of the catchment, in which industrial activity is dominated by electronics, metallurgy, building materials and the working of non-ferrous metals.

\section{Chemical analysis}

The top $2 \mathrm{~cm}$ of the river sediment was sampled using a customized device. The samples were initially frozen, and later analysed for the presence of eight heavy metals. The quantification of $\mathrm{Cu}, \mathrm{Zn}, \mathrm{Pb}, \mathrm{Cd}, \mathrm{Ni}$ and $\mathrm{Cr}$ content was conducted by first treating the sample with $\mathrm{HF}-\mathrm{HClO}_{4}$, and then subjecting the extract to atomic absorption spectrophotometry. The content of $\mathrm{Hg}$ and $\mathrm{As}$ was determined by extraction in, respectively, $\mathrm{H}_{2} \mathrm{SO}_{4}-\mathrm{HNO}_{3}-\mathrm{K}_{2} \mathrm{CrO}_{7}$ and $\mathrm{H}_{2} \mathrm{SO}_{4}-\mathrm{HNO}_{3}$ followed by atomic fluorescence. In order to check and control the probably pollution by samples during testing process, each sample analyzed by two blank whole-process. For the sake of ensure the validity of data and the accuracy and precision of analysis methods, the reference materials were adopted (Hg: GBW (E) 080392; As: GBW (E) 080390; Cd: GBW (E) 080401; Pb: GBW (E) 080399; Zn: GBW (E) 080400) Cu: GBW (E) 080396; Ni: GBW (E) 080392; Cr: GBW (E) 080403 [15]. The quality control gave good precision with a relative standard deviation better than $5 \%$ for all the duplicate samples.

\section{Analysis methods}

\section{Sediment quality assessment}

The extent of the pollution set against two threshold values, namely the "lowest effect screening level" (LEL) and the "severe effect screening level" (SEL). An LEL sediment is considered to be clean to marginally polluted, and is not expected to be deleterious to the majority of sediment-dwelling biota [16], whereas in SEL sediment, the level of pollution is high enough to compromise the survival of aquatic biota on a frequent basis [17]. Levels between LEL and SEL have a moderate impact on biota health, while levels above SEL are expected to severely impact upon biota heath [18].

\section{Potential ecological risk assessment}

The ecological risk assessment proposed by Hakanson [11] is based on the assumption that the sensitivity of an aquatic system depends on its productivity [8]. It is based on the following expressions [19]:

$$
\begin{gathered}
E_{r}^{i}=T_{r}^{i} \times C_{f}^{i} \\
C_{f}^{i}=C_{s}^{i} / C_{n}^{i} \\
R I=\sum E_{r}^{i}=\sum T_{r}^{i} \times C_{f}^{i}
\end{gathered}
$$


Here $T_{r}^{i}$ represents a toxic response factor for each given pollutant, $C_{f}^{i}$ the contamination factor for each heavy metal, $C_{s}{ }^{i}$ the measured level of each heavy metal in the sediment, $C_{n}{ }^{i}$ the background level of each heavy metal and $E_{r}{ }^{i}$ the potential ecological risk index. $R I$ is the sum of all risk factors. The sediments' heavy metal toxicity coefficient and geochemical background values are shown in Table 1. Grading standard of the heavy metal pollution ecological risk coefficient and index are detailed Table 2.

Table 1

$C_{n}{ }^{i}$ and $T_{r}{ }^{i}$ of the heavy metals of the sediments

\begin{tabular}{|c|c|c|c|c|c|c|c|c|}
\hline & Hg & As & Cu & Zn & Pb & Cd & Ni & Cr \\
\hline Background value ${ }^{*} C_{n}{ }^{i}\left[\mathrm{mg} \cdot \mathrm{kg}^{-1}\right]$ & 0.06 & 13.2 & 16.4 & 55 & 36.6 & 0.72 & 19.11 & 35 \\
\hline Toxicity coefficient $T_{r}^{i}$ & 40 & 10 & 5 & 1 & 5 & 30 & 5 & 2 \\
\hline
\end{tabular}

* The geochemical background value refers to the highest background of the heavy metal content in normal soil particles before modern industrialization [1]

Table 2

Grading of Hakanson potential ecological risk index

\begin{tabular}{|c|c|c|c|c|c|}
\hline & Low & Moderate & Considerable & High & Significantly high \\
\hline$E_{r}{ }^{i}$ & $<40$ & $\leq 80$ & $\leq 160$ & $\leq 320$ & $>320$ \\
\hline$R I$ & $<150$ & $\leq 300$ & $\leq 600$ & $>600$ & \\
\hline$R_{i}$ & 0 & 0.125 & 0.25 & 0.5 & 1 \\
\hline
\end{tabular}

\section{Economic Loss Estimation}

The economic loss caused by heavy metal pollution in the water was estimated from the following relationships:

$$
\begin{gathered}
H_{i}=\alpha \times \gamma_{i} \times R_{i} \\
H=\sum H_{i} \\
\gamma_{i}=E_{r}^{i} / R I
\end{gathered}
$$

Here $H$ represents the total economic loss caused by the heavy metal pollution; $\alpha$ the monetary loss coefficient $\left(\$ 8,498\right.$ per $\left.\mathrm{hm}^{2} \cdot \mathrm{a}\right)[20], \gamma_{i}$ the proportion of the potential ecological risk index accounted for by a specific heavy metal, and $R_{i}$ the weighting of ecological risk (Table 2). Inorganic pollutants in the river derive mainly from heavy metals, so the economic loss caused by heavy metal pollution represents $40 \%$ of the total loss [21]. As a result value of $\alpha$ was adjusted to $\$ 3,399.20 \mathrm{hm}^{2} \cdot \mathrm{a}$.

\section{Result and discussion}

\section{Distribution of heavy metals and the extent of pollution}

The measured heavy metal concentrations are detailed in Table 3. The mean sediment concentrations of $\mathrm{Hg}, \mathrm{As}, \mathrm{Cu}, \mathrm{Zn}, \mathrm{Pb}, \mathrm{Cd}$, $\mathrm{Ni}$ and $\mathrm{Cr}$ were, respectively 0.28, 21.83, 115.72, 188.64, 188.62, $0.41,36.67$ and $199.67 \mathrm{mg} \cdot \mathrm{kg}^{-1}$. The upstream sediments were considerably less polluted than the downstream ones, reflecting the effect of industrialization and urbanization in and around Qingyuan City. 
Concentrations of heavy metals in sediments of the Beijiang River $\left[\mathrm{mg} \cdot \mathrm{kg}^{-1}\right]$

\begin{tabular}{|c|c|c|c|c|c|c|c|c|c|}
\hline \multicolumn{2}{|c|}{ Site } & $\mathbf{H g}$ & $\mathbf{A s}$ & $\mathbf{C u}$ & $\mathbf{Z n}$ & $\mathbf{P b}$ & $\mathbf{C d}$ & $\mathbf{N i}$ & $\mathbf{C r}$ \\
\hline \multirow{4}{*}{$\begin{array}{c}\text { Upper stream } \\
\text { (Site 1-10) }\end{array}$} & Average & 0.15 & 17.31 & 49.20 & 142.52 & 128.18 & 0.48 & 31.46 & 122.38 \\
\cline { 2 - 10 } & Stdev & 0.04 & 2.37 & 21.78 & 37.87 & 17.83 & 0.84 & 8.10 & 44.79 \\
\cline { 2 - 10 } & Max & 0.18 & 19.50 & 110.00 & 176.00 & 145.00 & 2.86 & 38.20 & 161.00 \\
\cline { 2 - 10 }$y$ & Min & 0.04 & 11.50 & 36.60 & 41.20 & 81.80 & 0.18 & 10.00 & 14.80 \\
\hline \multirow{4}{*}{$\begin{array}{c}\text { Downstream } \\
\text { Site 11-19) }\end{array}$} & Average & 0.41 & 26.84 & 189.63 & 239.89 & 255.78 & 0.34 & 42.46 & 285.56 \\
\cline { 2 - 10 } & Stdev & 0.12 & 4.83 & 60.20 & 48.33 & 64.57 & 0.09 & 4.44 & 68.20 \\
\cline { 2 - 10 } & Max & 0.55 & 36.80 & 243.00 & 289.00 & 341.00 & 0.50 & 49.50 & 348.00 \\
\hline \multirow{4}{*}{ Average } & Min & 0.17 & 18.00 & 41.70 & 129.00 & 120.00 & 0.21 & 36.10 & 120.00 \\
\cline { 2 - 10 } & Average & 0.28 & 21.83 & 115.72 & 188.64 & 188.62 & 0.41 & 36.67 & 199.67 \\
\cline { 2 - 10 }$y$ & Mtdev & 0.16 & 6.09 & 83.89 & 65.19 & 79.35 & 0.60 & 8.57 & 100.39 \\
\cline { 2 - 10 }$y$ & Min & 0.55 & 36.80 & 243.00 & 289.00 & 341.00 & 2.86 & 49.50 & 348.00 \\
\cline { 2 - 9 } & 0.04 & 11.50 & 36.60 & 41.20 & 81.80 & 0.18 & 10.00 & 14.80 \\
\hline
\end{tabular}

Sediment quality guidelines of heavy metals in sediments of the Beijiang River $\left[\mathrm{mg} \cdot \mathrm{kg}^{-1}\right]$, [\%]

\begin{tabular}{|c|c|c|c|c|c|c|c|c|}
\hline Site & $\mathbf{H g}$ & $\mathbf{A s}$ & $\mathbf{C u}$ & $\mathbf{Z n}$ & $\mathbf{P b}$ & $\mathbf{C d}$ & $\mathbf{N i}$ & $\mathbf{C r}$ \\
\hline LEL & 0.15 & 8.20 & 16.00 & 120.00 & 16.00 & 1.20 & 16.00 & 26.00 \\
\hline SEL & 1.30 & 70.00 & 110.00 & 270.00 & 50.00 & 9.60 & 50.00 & 110.00 \\
\hline \% of samples < LEL & 10.50 & 0.00 & 0.00 & 5.30 & 0.00 & 94.70 & 5.30 & 5.30 \\
\hline Between LEL-SEL & 89.50 & 100.00 & 52.60 & 78.90 & 0.00 & 5.30 & 94.70 & 10.50 \\
\hline \% of samples > SEL & 0.00 & 0.00 & 47.40 & 15.80 & 100.00 & 0.00 & 0.00 & 84.20 \\
\hline
\end{tabular}

Table 5

Arsenic and heavy metal concentrations in sediment samples from the Beijiang River and other selected rivers from the literature $\left[\mathrm{mg} \cdot \mathrm{kg}^{-1}\right]$

\begin{tabular}{|c|c|c|c|c|c|c|c|c|c|}
\hline River & $\mathbf{H g}$ & As & $\mathbf{C u}$ & $\mathbf{Z n}$ & $\mathbf{P b}$ & Cd & $\mathbf{N i}$ & $\mathrm{Cr}$ & Reference \\
\hline $\begin{array}{l}\text { Upper stream of } \\
\text { Beijiang }\end{array}$ & $\begin{array}{l}0.04- \\
0.18\end{array}$ & $11.5-19.5$ & $\begin{array}{l}36.6- \\
110.0\end{array}$ & $\begin{array}{l}41.2- \\
176.0\end{array}$ & $\begin{array}{l}81.80- \\
145.0\end{array}$ & $\begin{array}{l}0.18- \\
0.24^{*}\end{array}$ & $10.0-38.2$ & $\begin{array}{l}14.8- \\
161.0\end{array}$ & This study \\
\hline $\begin{array}{c}\text { Downstream of } \\
\text { Beijiang }\end{array}$ & $\begin{array}{c}0.17- \\
0.55 \\
\end{array}$ & $18.0-36.8$ & $\begin{array}{l}41.7- \\
243.0 \\
\end{array}$ & $\begin{array}{l}129.0- \\
289.0 \\
\end{array}$ & $\begin{array}{l}120.0- \\
341.0 \\
\end{array}$ & $0.21-0.50$ & $36.1-49.5$ & $\begin{array}{l}120.0- \\
348.0 \\
\end{array}$ & This study \\
\hline Pearl River, China & -- & -- & $\begin{array}{l}101.8- \\
829.4\end{array}$ & $\begin{array}{l}172.6- \\
560.7 \\
\end{array}$ & $\begin{array}{l}43.8- \\
219.6 \\
\end{array}$ & $0.21-4.15$ & -- & $6.7-215.5$ & {$[24]$} \\
\hline Huaihe River, China & -- & -- & $\begin{array}{l}16.0- \\
46.30\end{array}$ & $53.0-93.0$ & $\begin{array}{l}17.6- \\
29.5\end{array}$ & $0.13-0.24$ & -- & $45.8-71.5$ & {$[25]$} \\
\hline Yangtze River, China & $\begin{array}{c}0.04- \\
1.43 \\
\end{array}$ & 7.9-29.9 & $\begin{array}{l}26.0- \\
129.0\end{array}$ & $\begin{array}{c}71.0- \\
1142.0\end{array}$ & $\begin{array}{c}20.0- \\
98.0\end{array}$ & $0.20-3.40$ & $26.0-57.0$ & $\begin{array}{l}57.0- \\
205.0\end{array}$ & {$[26]$} \\
\hline Yellow River, China & -- & -- & $11.0-34.9$ & $\begin{array}{l}51.1- \\
133.8 \\
\end{array}$ & $\begin{array}{l}17.4- \\
55.1\end{array}$ & $0.07-1.41$ & $14.4-59.1$ & $\begin{array}{l}30.9- \\
102.7\end{array}$ & [27] \\
\hline Luan River, China & $\begin{array}{c}0.01- \\
1.39 \\
\end{array}$ & $2.1-12.9$ & $6.5-178.6$ & $21.1-25.7$ & $8.7-38.3$ & $0.03-0.37$ & -- & $\begin{array}{l}28.7- \\
152.7\end{array}$ & {$[15]$} \\
\hline $\begin{array}{c}\text { River Yeşilırmak, } \\
\text { Turkey }\end{array}$ & -- & -- & $\mid 13.1-38.7$ & $24.7-45.5$ & $3.3-17.3$ & $0.12-0.55$ & $15.4-79.2$ & -- & {$[25]$} \\
\hline Tigris River, Turkey & -- & $2.0-18.0$ & $\begin{array}{c}11.2- \\
5075.6 \\
\end{array}$ & $\begin{array}{c}60.1- \\
2396.0\end{array}$ & $\begin{array}{l}62.3- \\
566.6 \\
\end{array}$ & $0.70-4.90$ & $\begin{array}{l}74.0- \\
288.0\end{array}$ & $\begin{array}{l}28.4- \\
151.7\end{array}$ & [23] \\
\hline Guadiana, SW Iberian & $\begin{array}{c}0.16- \\
4.43 \\
\end{array}$ & $8.8-55.6$ & 7.5-71.9 & $\begin{array}{c}102.0- \\
483.0\end{array}$ & $\begin{array}{c}22.9- \\
47.9 \\
\end{array}$ & $0.10-1.40$ & $20.8-38.1$ & $14.0-49.0$ & {$[22]$} \\
\hline
\end{tabular}

* We dismissed the site 7 of $\mathrm{Cd}$, which may be caused by sampling error 
a

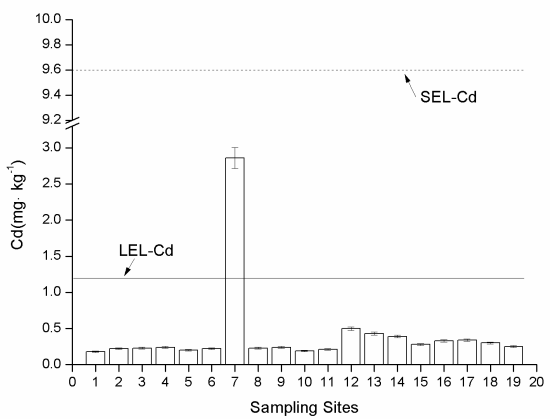

c

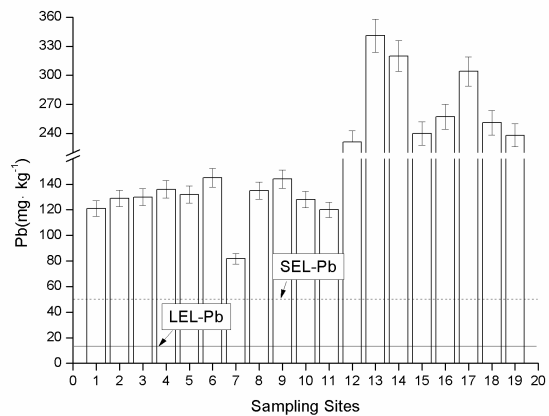

e

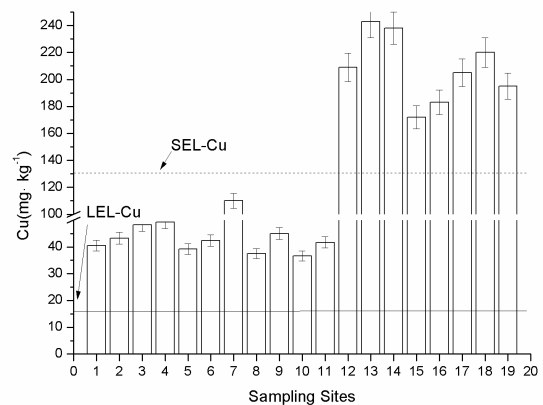

g

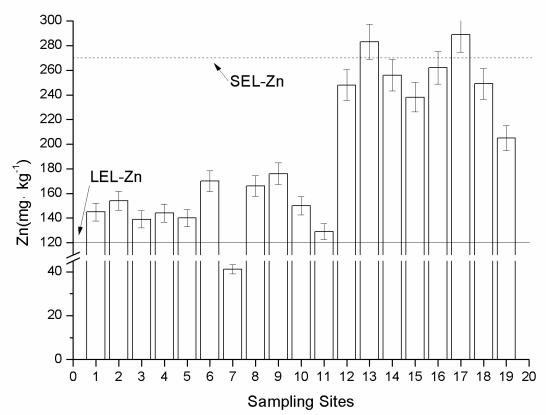

b

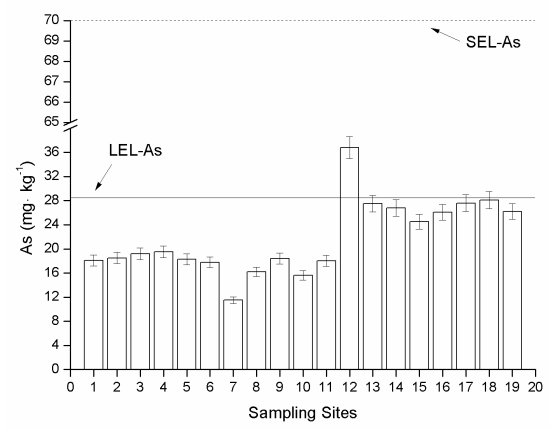

d

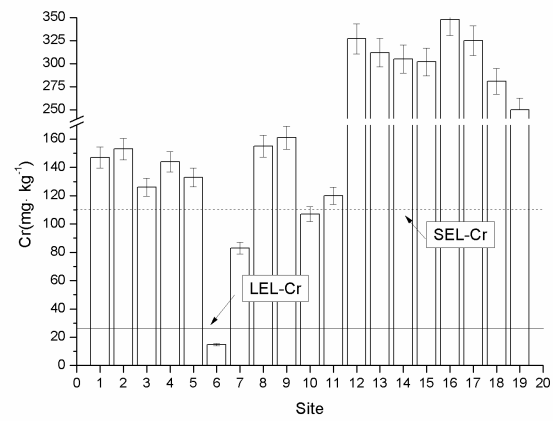

f

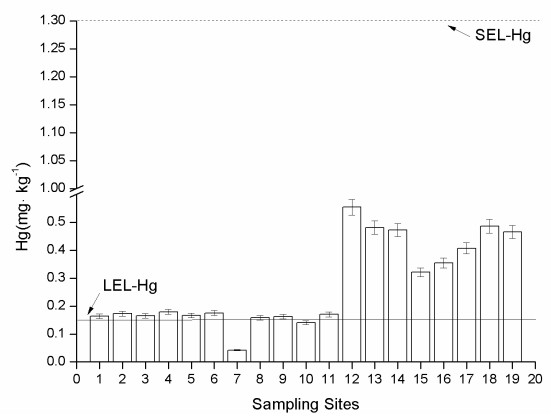

h

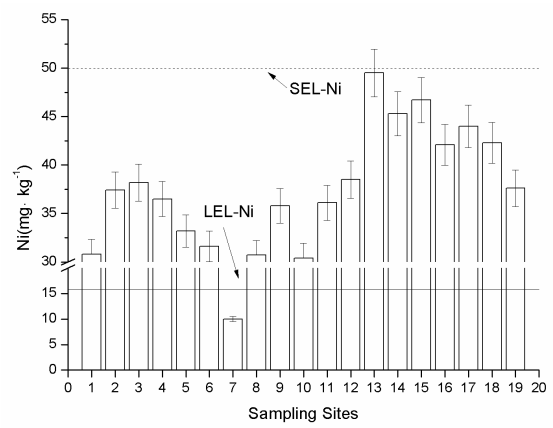

Fig. 2. Heavy metal concentrations of each sampling transects 
According to the SQG methodology, the measured heavy metal concentrations in the river sediment samples were compared to consensus-based SEL and LEL values (Table 4). All of the pollutants, except for Cd (the concentration of Cd exceeded its LEL only at site \#7, located downstream of a sewage treatment plant) and As (the concentration of Cd exceeded its LEL only at site \#12, located downstream of Qingxin County), exceeded their respective LEL (Fig. 2a, 2b).; those for Pb and Cr even exceeded their SEL (Fig. 2c, 2d). For $\mathrm{Cu}$, the latter was the case for eight of the 19 samples (Fig. 2e). The concentrations of $\mathrm{Hg}, \mathrm{Zn}$ and $\mathrm{Ni}$ exceeded their LELs in respectively 16, 17 and 18 of the 19 samples (Fig 2f-2h). The levels of Hg, As, Zn and Ni lay between their LEL and SEL at only a few sites. The concentration of $\mathrm{Hg}, \mathrm{Zn}$ and $\mathrm{Ni}$ at site \#7 was below the respective LEL, while the $\mathrm{Zn}$ concentration exceeded its LEL at sites \#13, \#14 and \#17. Except at sites \#6, \#7 and $\# 10$, the concentration of $\mathrm{Cr}$ was uniformly higher than its SEL. For $\mathrm{Cu}$, this also applied to sites \#12 through \#19, while at the remaining sites, the level was >LEL. Similarly for Pb, all sites sampled were polluted at a level $>$ SEL (Fig. 2).

A comparison between the heavy metal concentrations in the sediment of the Beijiang River with those in other river sediments is shown in Table 5. This shows that in the upstream reaches of the Beijiang river, pollution levels were similar to that present in most rivers, but in its downstream reaches, $\mathrm{Cr}$ pollution was particularly severe, while that of both $\mathrm{As}$ and $\mathrm{Pb}$ was only exceeded in the Guadiana [22] and Tigris [23].

\section{Potential ecological risk assessment}

The calculated potential ecological risk and potential toxicity response indices are given in Table 6. In the upstream sites \#1-\#10, the RI value lay between 150 and 300 (mean of 185.2), while the mean RI in the downstream sites \#11-\#19 was 433.7. Both the up and downstream reaches of the river were associated with potential ecological risk, but the level of risk in the downstream reaches was considerable. The mean ecological risk factors $\left(E_{r}^{i}\right)$ of $\mathrm{As}, \mathrm{Zn}, \mathrm{Pb}, \mathrm{Ni}$ and $\mathrm{Cr}$ were all $<40$ (low ecological risk), but that for $\mathrm{Hg}$ in the upstream reaches was 101.7, a value lying in the range associated with considerable risk. The downstream mean $\operatorname{Hg} E_{r}^{i}$ was 274.8 (reaching 369.3 at one site), representing a high to very high ecological risk. Similarly the concentration of $\mathrm{Cd}$ at site \#7 was high enough to give an $E_{r}^{i}$ of $>80$ (medium risk level).

Table 6 Ecological risk factor (Eri) and the potential ecological risk index $(R I)$ of heavy metals in surface sediments of the Beijiang river

\begin{tabular}{|c|c|c|c|c|c|c|c|c|c|}
\hline Site & $\mathbf{H g}$ & $\mathbf{A s}$ & $\mathbf{C u}$ & $\mathbf{Z n}$ & $\mathbf{P b}$ & $\mathbf{C d}$ & $\mathbf{N i}$ & $\mathbf{C r}$ & $\boldsymbol{R I}$ \\
\hline 1 & 109.33 & 13.71 & 12.35 & 2.64 & 16.53 & 7.50 & 8.06 & 8.40 & 178.52 \\
\hline 2 & 115.33 & 14.02 & 13.20 & 2.80 & 17.62 & 9.17 & 9.79 & 8.74 & 190.67 \\
\hline 3 & 110.00 & 14.55 & 14.70 & 2.53 & 17.76 & 9.58 & 9.99 & 7.20 & 186.31 \\
\hline 4 & 119.33 & 14.77 & 15.03 & 2.62 & 18.58 & 10.00 & 9.55 & 8.23 & 198.11 \\
\hline 5 & 110.67 & 13.86 & 11.95 & 2.55 & 18.03 & 8.33 & 8.69 & 7.60 & 181.68 \\
\hline 6 & 116.67 & 13.48 & 12.93 & 3.09 & 19.81 & 9.17 & 8.27 & 0.85 & 184.27 \\
\hline 7 & 28.00 & 8.71 & 33.54 & 0.75 & 11.17 & $\mathbf{1 1 9 . 1 7}$ & 2.62 & 4.74 & 208.70 \\
\hline 8 & 105.33 & 12.27 & 11.43 & 3.02 & 18.44 & 9.58 & 8.03 & 8.86 & 176.96 \\
\hline 9 & 108.67 & 13.94 & 13.72 & 3.20 & 19.67 & 10.00 & 9.37 & 9.20 & 187.77 \\
\hline 10 & 93.33 & 11.82 & 11.16 & 2.73 & 17.49 & 7.92 & 7.95 & 6.11 & 158.51 \\
\hline Average of upper stream & 101.67 & 13.11 & 15.00 & 2.59 & 17.51 & 20.04 & 8.23 & 6.99 & 185.15 \\
\hline Stdev of upper stream & 26.86 & 1.80 & 6.64 & 0.69 & 2.44 & 34.84 & 2.12 & 2.56 & 13.31 \\
\hline
\end{tabular}




\begin{tabular}{|c|c|c|c|c|c|c|c|c|c|}
\hline Site & Hg & As & $\mathbf{C u}$ & $\mathbf{Z n}$ & $\mathbf{P b}$ & $\mathbf{C d}$ & $\mathbf{N i}$ & $\mathbf{C r}$ & $\boldsymbol{R I}$ \\
\hline 11 & 113.33 & 13.64 & 12.71 & 2.35 & 16.39 & 8.75 & 9.45 & 6.86 & 183.48 \\
\hline 12 & $\mathbf{3 6 9 . 3 3}$ & 27.88 & 63.72 & 4.51 & 31.56 & 20.83 & 10.07 & 18.69 & $\mathbf{5 4 6 . 5 9}$ \\
\hline 13 & $\mathbf{3 2 0 . 6 7}$ & 20.83 & 74.09 & 5.15 & 46.58 & 17.92 & 12.95 & 17.83 & $\mathbf{5 1 6 . 0 2}$ \\
\hline 14 & 314.67 & 20.30 & 72.56 & 4.65 & 43.72 & 16.25 & 11.85 & 17.43 & $\mathbf{5 0 1 . 4 3}$ \\
\hline 15 & 214.00 & 18.56 & 52.44 & 4.33 & 32.79 & 11.67 & 12.22 & 17.26 & $\mathbf{3 6 3 . 2 7}$ \\
\hline 16 & 236.00 & 19.77 & 55.79 & 4.76 & 35.11 & 13.75 & 11.02 & 19.89 & $\mathbf{3 9 6 . 0 9}$ \\
\hline 17 & 271.33 & 20.91 & 62.50 & 5.25 & 41.53 & 14.17 & 11.51 & 18.57 & $\mathbf{4 4 5 . 7 7}$ \\
\hline 18 & $\mathbf{3 2 4 . 0 0}$ & 21.29 & 67.07 & 4.53 & 34.29 & 12.50 & 11.07 & 16.06 & $\mathbf{4 9 0 . 8 1}$ \\
\hline 19 & 310.00 & 19.85 & 59.45 & 3.73 & 32.51 & 10.42 & 9.84 & 14.29 & $\mathbf{4 6 0 . 0 9}$ \\
\hline Average of downstream & 274.81 & 20.34 & 57.81 & 4.36 & 34.94 & 14.03 & 11.11 & 16.32 & $\mathbf{4 3 3 . 7 3}$ \\
\hline Stdev of downstream & 77.12 & 3.66 & 18.35 & 0.88 & 8.82 & 3.80 & 1.16 & 3.90 & 110.23 \\
\hline
\end{tabular}

The analysis suggested that the severity of the ecological risk among the heavy metals can be ranked $\mathrm{Hg}>\mathrm{Cd}>\mathrm{Cu}>\mathrm{Pb}>\mathrm{As}>\mathrm{Cr}>\mathrm{Ni}>\mathrm{Zn}$. $\mathrm{Hg}$ is the most hazardous of these pollutants not because of its high concentration so much as because of its high toxicity. Based on RI values, it appeared that the upstream reaches of the Beijiang River were still relatively unpolluted, but that the heavily urbanized downstream reaches were seriously polluted.

\section{Economic loss calculation}

The estimated economic losses due to polluted sediment are detailed in Table 7. The global loss for the upstream reaches of the river was estimated as $\$ 466.63 \mathrm{per} \mathrm{hm}^{2} \cdot \mathrm{a}$ while that for the downstream reaches was $\$ 1,133.52$ per $\mathrm{hm}^{2}$.a. Even though the lower concentration of $\mathrm{Hg}$ and $\mathrm{Cd}$, economic loss coursed by them were higher than other heavy metals because of the highest toxicity coefficient.

Sediment plays an important role in maintaining the fluvial environment, and the diversity of ecosystem services is dependent on the sediment's quantity [28]. The sediment is a major determinant of both economic efficiency, environmental protection and ecosystem sustainability. The estimated economic loss due to heavy metal pollution in the Beijiang River varied from about $\$ 500 \mathrm{per} \mathrm{hm}^{2} \cdot \mathrm{a}$ in its upstream reaches to $>\$ 1,100$ per $\mathrm{hm}^{2} \cdot \mathrm{a}$ in its downstream reaches. These figures represent an appreciable (around $5.5 \%$ and $13.3 \%$, respectively) loss to the economic value of the upstream and downstream ecosystem services. As a result of anthropogenic activity, pollution of the fluvial sediment has become an environmental problem [29], since heavy metals such as $\mathrm{Hg}, \mathrm{As}, \mathrm{Cu}, \mathrm{Zn}, \mathrm{Pb}, \mathrm{Cd}, \mathrm{Ni}$ and $\mathrm{Cr}$ are very persistent in the sediment and are known to be detrimental to aquatic ecosystems, fisheries and water quality [30]. They have a tendency to accumulate in the food chain, and also compromise the soil ecosystem [31].

Heavy metals economic loss $\left[\$\right.$ per $\left.\mathrm{hm}^{2} \cdot \mathrm{a}\right]$

\begin{tabular}{|c|c|c|c|c|c|c|c|c|c|}
\hline Hi & $\mathbf{H g}$ & $\mathbf{A s}$ & $\mathbf{C u}$ & $\mathbf{Z n}$ & $\mathbf{P b}$ & $\mathbf{C d}$ & $\mathbf{N i}$ & $\mathbf{C r}$ & $\mathbf{H}$ \\
\hline upper stream & 466.63 & 0.00 & 0.00 & 0.00 & 0.00 & 0.00 & 0.00 & 0.00 & 466.63 \\
\hline downstream & 1076.88 & 0.00 & 56.64 & 0.00 & 0.00 & 0.00 & 0.00 & 0.00 & 1133.52 \\
\hline
\end{tabular}

A whole suite of human activity, including mining, industry, agriculture, fuel consumption and waste disposal, has been responsible for the growing accumulation of heavy metals and other pollutants in fluvial sediments $[28,32]$. Heavy polluters, such as the electronics and electroplating industries, routinely discharge waste water containing 
a substantial load of heavy metals [33]. Counter-measures against sediment pollution will therefore require adjustments to industrial practices and the sitting of industrial plants, particularly where the waste products include $\mathrm{Hg}, \mathrm{Cr}$ and/or $\mathrm{Cd}$. The consequence of economic loss from heavy metals would be contribute to the government make decision scientific. The present estimates of the economic loss caused by heavy metal pollution are likely to be on the conservative side as a result of the location of the sampling sites. Further more, the loss of environment pollution time effect not taken into account, so, it is necessary to have a further study on higher accuracy, more economical and practical and consider comprehensive method to control the losses which caused by environmental pollution.

\section{Conclusions}

Nearly all of the heavy metal concentrations were elevated in the Beijiang River sediments, although the upstream sediments were clearly less polluted than were the downstream ones. The upstream reaches of the river presented a moderate ecological risk, but the risk in the downstream reaches was relatively high. The economic loss associated with heavy metal pollution was predominantly caused by the presence of $\mathrm{Hg}$; it represented about $5.5 \%$ (upstream reaches) and $13.3 \%$ (downstream reaches) of the value of the river ecosystem services. A significant reduction in the discharge of industrial effluent and domestic sewage will be necessary to improve the quality of the river water.

\section{Acknowledgments}

Thanks to financial support from the National Nature Science Foundation of China (41101494) and the Fundamental Research Funds for the Central Universities (2011QC092).

\section{References}

[1] Zhang C, Qiao Q, Piper JDA, Huang B. Assessment of heavy metal pollution from a Fe-smelting plant in urban river sediments using environmental magnetic and geochemical methods. Environ Pollut. 2011;159(10):3057-3070.

[2] Li Y, Liu J, Cao Z, Lin C, Yang Z. Spatial distribution and health risk of heavy metals and polycyclic aromatic hydrocarbons (PAHs) in the water of the Luanhe River Basin, China. Environ Monit Assess. 2010;163(1):1-13.

[3] Man YB, Sun XL, Zhao YG, Lopez BN, Chung SS, Wu SC, et al. Health risk assessment of abandoned agricultural soils based on heavy metal contents in Hong Kong, the world's most populated city. Environ Internat. 2010;36(6):570-576.

[4] Mohiuddin K, Zakir H, Otomo K, Sharmin S, Shikazono N. Geochemical distribution of trace metal pollutants in water and sediments of downstream of an urban river. Int $\mathbf{J}$ Environ Sci Technol. 2010;7(1):17-28.

[5] Listowski A, Ngo HH, Guo WS. Establishment of an economic evaluation model for urban recycled water. Resour Conserv Recycling. 2013;72(0):67-75.

[6] Liu F, Yan W, Wang W, Gu S, Chen Z. Pollution of heavy metals in the Pearl River Estuary and its assessment of potential ecological risk. Marine Environ Sci. 2002;21(3):34-38.

[7] Bai J, Cui B, Chen B, Zhang K, Deng W, Gao H, et al. Spatial distribution and ecological risk assessment of heavy metals in surface sediments from a typical plateau lake wetland, China. Ecol Modell. 2011;222(2):301-306

[8] Yi Y, Yang Z, Zhang S. Ecological risk assessment of heavy metals in sediment and human health risk assessment of heavy metals in fishes in the middle and lower reaches of the Yangtze River basin. Environ Pollut. 2011;159(10): 2575-2585. 
[9] Bai J, Xiao R, Cui B, Zhang K, Wang Q, Liu X, et al. Assessment of heavy metal pollution in wetland soils from the young and old reclaimed regions in the Pearl River Estuary, South China. Environ Pollut. 2011;159(3):817-824

[10] Song MW, Huang P, Li F, Zhang H, Xie KZ, Wang XH, et al. Water quality of a tributary of the Pearl River, the Beijiang, Southern China: implications from multivariate statistical analyses. Environ Monit Assess. 2011;172(1):589-603.

[11] Håkanson L. An ecological risk index for aquatic pollution control. A sedimentological approach. Water Res. 1980;14(8):975-1001.

[12] Costanza R, d'Arge R, de Groot R, Farber S, Grasso M, Hannon B, et al. The value of the world's ecosystem services and natural capital. Ecol Econom. 1998;25(1):3-15.

[13] Chen L, Huang Y, Peng X, Xu Z, Zhang S, Ren M, et al. PBDEs in sediments of the Beijiang River, China: Levels, distribution, and influence of total organic carbon. Chemosphere. 2009;76(2):226-231.

[14] Ye F, Huang X, Zhang D, Tian L, Zeng Y. Distribution of heavy metals in sediments of the Pearl River Estuary, Southern China: Implications for sources and historical changes. J Environ Sci. 2012;24(4):579-588.

[15] Liu J, Li Y, Zhang B, Cao J, Cao Z, Domagalski J. Ecological risk of heavy metals in sediments of the Luan River source water. Ecotoxicology. 2009;18(6):748.

[16] Ramiro Pastorinho M, Telfer T, Nogueira AA, Soares AVM, Ranville J. An evaluation of trace metal distribution, enrichment factors and risk in sediments of a coastal lagoon (Ria de Aveiro, Portugal). Environ Earth Sci. 2012;67(7):2043-2052

[17] Smith SL, MacDonald DD, Keenleyside KA, Ingersoll CG, Jay Field L. A preliminary evaluation of sediment quality assessment values for freshwater ecosystems. J Great Lakes Res. 1996;22(3):624-638.

[18] Graney JR, Eriksen TM. Metals in pond sediments as archives of anthropogenic activities: a study in response to health concerns. Appl Geochem. 2004;19(7):1177-1188.

[19] Huang H, Yuan X, Zeng G, Zhu H, Li H, Liu Z, et al. Quantitative evaluation of heavy metals' pollution hazards in liquefaction residues of sewage sludge. Bioresour Technol. 2011;102(22):10346-10351.

[20] Costanza R, Arge D, Groot D. The value of ecosystem service and nature capital in the world. Nature. 1997;387(15):235-260.

[21] Liu S, Dong X, Li Z, Li J. Construction and application of estimation model of economic loss from heavy metal pollution. Environ Protect Sci. 2010;36(3):81-84.

[22] Delgado J, Barba-Brioso C, Nieto JM, Boski T. Speciation and ecological risk of toxic elements in estuarine sediments affected by multiple anthropogenic contributions (Guadiana saltmarshes, SW Iberian Peninsula): I. Surficial sediments. Sci Total Environ. 2011;409(19): 666-3679.

[23] Varol M. Assessment of heavy metal contamination in sediments of the Tigris River (Turkey) using pollution indices and multivariate statistical techniques. J Hazard Mater. 2011;195: 355-364

[24] Niu H, Deng W, Wu Q, Chen X. Potential toxic risk of heavy metals from sediment of the Pearl River in South China. J Environ Sci. 2009;21(8):1053-1058. DOI: 10.1016/S1001-0742(08)62381-5.

[25] Mendil D, Ünal ÖF, Tüzen M, Soylak M. Determination of trace metals in different fish species and sediments from the River Yeşilırmak in Tokat, Turkey. Food Chem Toxicol. 2010;48(5):1383-1392.

[26] Yang Z, Wang Y, Shen Z, Niu J, Tang Z. Distribution and speciation of heavy metals in sediments from the mainstream, tributaries, and lakes of the Yangtze River catchment of Wuhan, China. J Hazard Mater. 2009;166(2-3):1186-1194.

[27] Feng J, Wang G, Sun J, Sun S, Liu X. Metals in water and surface sediments from Henan reaches of the Yellow River, China. Sci China Chem. 2010;53(5):1217-1224.

[28] Apitz SE. Conceptualizing the role of sediment in sustaining ecosystem services: Sediment-ecosystem regional assessment (SEcoRA). Sci Total Environ. 2012;415:9-30.

[29] Singare PU, Mishra RM, Trivedi MP. Sediment contamination due to toxic heavy metals in Mithi River of Mumbai. Adv Anal Chem. 2012;2(3):14-24.

[30] Yoon J, Cao X, Zhou Q, Ma LQ. Accumulation of $\mathrm{Pb}, \mathrm{Cu}$, and $\mathrm{Zn}$ in native plants growing on a contaminated Florida site. Sci Total Environ. 2006;368(2):456-464.

[31] Gómez-Sagasti MT, Alkorta I, Becerril JM, Epelde L, Anza M, Garbisu C. Microbial monitoring of the recovery of soil quality during heavy metal phytoremediation. Water Air Soil Pollut. 2012;233(6):3249-3262.

[32] Wei B, Yang L. A review of heavy metal contaminations in urban soils, urban road dusts and agricultural soils from China. Microchem J. 2010;94(2):99-107. 
[33] Gu YG, Wang ZH, Lu SH, Jiang SJ, Mu DH, Shu YH. Multivariate statistical and GIS-based approach to identify source of anthropogenic impacts on metallic elements in sediments from the mid Guangdong coasts, China. Environ Pollut. 2012;163:248-255.

\title{
OCENA RYZYKA EKOLOGICZNEGO I STRAT EKONOMICZNYCH WYNIKAJĄCYCH Z ZANIECZYSZCZENIA METALAMI CIĘŻKIMI RZEKI BEIJIANG
}

\begin{abstract}
Abstrakt: W artykule opisano dystrybucję i stopień akumulacji metali ciężkich w rzecznych osadach rzeki Beijiang. Potencjalną toksyczność tych zanieczyszczeń obliczono za pomocą metody wytycznych jakości osadów (SQGs) opartej na konsensusie i za pomocą potencjalnego wskaźnika ryzyka ekologicznego Håkansona. Stężenia $\mathrm{Hg}, \mathrm{As}, \mathrm{Cu}, \mathrm{Zn}, \mathrm{Pb}$, Ni i Cr były na tyle wysokie, aby uszkodzić biocenozy osadu. Potencjalne ryzyko ekologiczne było znacznie większe w dalszych, zurbanizowanych odcinkach rzeki niż na wcześniejszych odcinkach, które nadal są wiejskie, ale wszystkie odcinki rzeki reprezentowały co najmniej umiarkowany poziom ryzyka ekologicznego. Szacunki strat ekonomicznych związanych z tymi zanieczyszczeniami były znaczne, a to głównie ze względu na obecność $\mathrm{Hg}$ i Cu. Dorzecze rzeki Beijiang jest mocno zanieczyszczone, stwarzając zagrożenie dla środowiska w dalszym biegu rzeki Perłowej i możliwość strat ekonomicznych dla całej zlewni.
\end{abstract}

Słowa kluczowe: ocena ryzyka ekologicznego, oszacowanie strat ekonomicznych, metale ciężkie, osady, odnowa ekosystemu, rzeka Beijiang 